\author{
Kiszely Zoltán \\ Budapesti Müszaki és Gazdaságtudományi Egyetem \\ Gazdaság- és Társadalomtudományi Kar \\ Idegen Nyelvi Központ
}

\title{
Államilag elismert szaknyelvi vizsgák a Porta Linguában
}

\author{
https://doi.org/10.48040/PL.2020.28
}

\begin{abstract}
Jelen irás azt vizsgálja, hogy az idén 20 éves államilag elismert szaknyelvi vizsgáztatás témaköre hogyan jelenik meg a 2002 óta kiadott Porta Lingua szaknyelvi tanulmányokat tartalmazó sorozat köteteiben, azaz a cikk megkísérli felrajzolni a szaknyelvi vizsgák kutatásának ivét és szerepét a magyarországi nyelvvizsgáztatás újkori történetében. Az irásban bemutatjuk azokat a témaköröket, amelyek a kutatókat az évek során leginkább foglalkoztatták, úgymint a szaknyelv és mérésének mibenléte, a Közös Európai Referenciakerethez (KER) történö szintillesztés, az eredményszámítási vizsgálatok, a szükségletelemzés, a vizsgák érvényességének folyamatos fenntartása és a közvetitő készség. A különbözö szaknyelvek közül a legtöbb irás a gazdasági, az üzleti és az egészségügyi nyelvvizsgákkal foglalkozott, jelen pillanatban pedig a legkurrensebb téma a tudományos szaknyelv kutatása. Megállapítjuk azt is, hogy a Porta Lingua eddigi 18 éves története során összességében nagyon kevés cikk fókuszált az államilag elismert szaknyelvi vizsgáztatás témakörére, amelynek lehetséges okaira is röviden kitérünk.
\end{abstract}

Kulcsszavak: államilag elismert szaknyelvi vizsga, nyelvhasználat, Porta Lingua, szakma, történeti áttekintés

\section{Bevezetés}

A magyarországi nyelvi méréssel és értékeléssel foglalkozó szakemberek számára jól ismert tény, hogy 2000. január 1-jétől új korszak kezdődött a magyarországi nyelvvizsgáztatás történetében, ugyanis az állami nyelvvizsga szerepét átvették az államilag elismert nyelvvizsgák és ezzel párhuzamosan felszabadult a nyelvvizsgapiac, azaz számos nyelvvizsgaközpont alakult. Jelen pillanatban, amikor az államilag elismert nyelvvizsgáztatás fennállása 20. évfordulóját ünnepli, 26 központ kínál nyelvvizsgákat, amelyek közül 15 szaknyelvi vizsgákat is szervez.

A szaknyelvekkel foglalkozó szakemberek számára köztudott, hogy a szaknyelvi tanulmányokat tartalmazó Porta Lingua tanulmánykötet-sorozat 2002 óta jelenik meg. A sorozat szinte minden kötetében fellelhetőek szaknyelvi vizsgáztatással kapcsolatos cikkek. Mivel mindkét alkalmazott nyelvészeti indíttatású ,jelenség", az újkori nyelvvizsgáztatás és a Porta Lingua gyakorlatilag egyidős és még a felnőttkorba is egyszerre lép, ezért 
érdemes visszapillantani az elmúlt évekre és megvizsgálni, hogy a szaknyelvi vizsgáztatással kapcsolatban milyen publikációk jelentek meg ebben a kiadványban, azaz milyen tudományos háttérre támaszkodtak az egyes vizsgaközpontok és ez a háttér hogyan változott az elmúlt két évtizedben.

A Porta Lingua sorozatban nem ez az első írás, amely a kötetekben megjelent cikkeket rendszerezi valamilyen szempont alapján. Sturcz már 2007-ben arra mutatott rá, hogy a sorozat óriási forrásanyagot jelent az oktatás, a módszertan, és a kutatás számára, Fischer (2016) pedig a 2002 és 2014 között megjelent kötetekben azt vizsgálta, hogy a szaknyelvek kutatásának mely területei voltak hangsúlyosak és kevésbé hangsúlyosak az egyes időszakokban. Ugyanő azt is megjegyzi, hogy a mérés-értékelés témakörben kevés cikk jelent meg és azok is elsősorban a nyelvvizsgáztatásról szólnak. Ez a tény vitathatatlan, de megítélésem szerint a kevés cikk ellenére mégis érdemes megvizsgálni a szaknyelvi akkreditált vizsgáztatás témakörében született tanulmányokat, mert ez alapján kitapinthatóak bizonyos tendenciák a szaknyelvi vizsgákkal kapcsolatos kutatási fókuszok változásairól.

Először a mennyiségi mutatókkal foglalkozunk, azaz megnézzük, hogy hány cikk foglalkozott a témával és ezek milyen részterületeket fedtek le. Ezt követően a témakörök és a kronológia egyszerre történő figyelembevételével vizsgáljuk meg az írásokat. A tanulmányban kizárólag azokat a cikkeket vesszük figyelembe, amelyek fókusza konkrétan az államilag elismert nyelvvizsgáztatásra irányul, tehát azokkal, amelyek csak általánosságban a vizsgákra való felkészítésről szólnak, nem foglalkozunk.

\section{Általános jellemzők}

A Porta Linguában megjelent cikkekről megállapítható, hogy bizonyára a terjedelmi korlátok miatt, nem számolnak be nagyszabású kutatásokról, hanem inkább egy-egy részproblémára koncentrálnak. A 18 kötetben összesen 39 magyar és három angol nyelvủ a szaknyelvi államilag elismert nyelvvizsgáztatással foglalkozó cikket találtunk, amelyek a következő föbb témakörökkel foglalkoznak: nyelvi tesztelés általános kérdései, szaknyelvi vizsgák mibenléte, KER illesztés, szükségletelemzés, vizsgafejlesztés, készségek mérése, eredményszámítási módszerek, szaknyelv fajták. Mivel egy cikk egyszerre több témakörhöz is tartozik, például a gazdasági nyelvvizsgák szintillesztése egyszerre kapcsolódik a szaknyelv-fajták és a szintillesztés témájához, ezért nem számoltuk össze, hogy a 42 tanulmány egyenként hova sorolható. 
A számszerü közlés azonban értelmet nyer akkor, ha azt vizsgáljuk, hogy az egyes években hány tanulmány foglalkozott a szaknyelvi vizsgáztatással.

1. táblázat. Szaknyelvi tanulmányok száma éves bontásban

\begin{tabular}{|c|c|}
\hline Év & Cikkek száma \\
\hline 2002 & 2 \\
\hline 2003 & 2 \\
\hline 2004 & 5 \\
\hline 2005 & 5 \\
\hline 2006 & 8 \\
\hline 2007 & 2 \\
\hline 2008 & 2 \\
\hline 2009 & 0 \\
\hline 2010 & 2 \\
\hline
\end{tabular}

\begin{tabular}{|c|c|}
\hline Év & Cikkek száma \\
\hline 2011 & 1 \\
\hline 2012 & 0 \\
\hline 2013 & 2 \\
\hline 2014 & 2 \\
\hline 2015 & 1 \\
\hline 2016 & 2 \\
\hline 2017 & 1 \\
\hline 2018 & 2 \\
\hline 2019 & 3 \\
\hline
\end{tabular}

Az 1. táblázatból kiolvasható, hogy a szaknyelvi vizsgák hajnalán sokkal nagyobb érdeklödést mutattak a kutatók a szaknyelvi vizsgák tudományos igényü feldolgozása iránt, mint a későbbiekben, hiszen az első öt évben (2002-2006) 22 cikk, míg a következő 13 év alatt (2007-2019) csupán 20 tanulmány foglalkozott a témával. Ebböl arra lehet következtetni, hogy egyre kevésbé játszik fontos szerepet a szaknyelvi vizsgáztatás a szaknyelvi kutatások között.

\section{A nyelvi tesztelésről általában}

A következökben a fent említett föbb témakörök szerint csoportosítva foglaljuk össze az egyes cikkek legfontosabb megállapításait. Az összes megjelent cikkre természetesen nem utalhatunk, mert az meghaladná a tanulmány terjedelmi kereteit.

Érdekes módon a nyelvi tesztelés általános jellemzőiről a második és az eddigi utolsó elötti kötetben találunk egy-egy tanulmányt. A 2003-as kötetben Dévény az idegen nyelvi tesztelés etikai kérdéseit boncolgatja. Abból indul ki, hogy mivel a tesztek szükségszerüen tökéletlenek, a tesztelési szakembereknek óriási a társadalmi felelössége, hiszen az ezen a mérőeszközön elért eredmény számtalan ember későbbi életét határozhatja meg gyökeresen. Boncolgatja továbbá az elszámoltathatóság és a tesztek visszahatásának etikai vonatkozásait és bemutatja az ILTA Etikai Kódexét is. A másik cikk, amely 15 évvel később, 2018-ban látott napvilágot (Kiszely, 2018) bizonyos szempontból szintén a tesztek visszahatásáról szól, ugyanis a vizsgáztatás és a nyelvoktatás közötti párhuzamokat elemzi, valamint azt vizsgálja, hogy a nyelvvizsgáztatás során felhalmozott tudás és tapasztalat 
hogyan hasznosulhat a nyelvoktatás mindennapjaiban. Az előző cikk elsősorban szakirodalomra támaszkodott, míg a második a szerző saját tapasztalatait foglalta össze és azok közül is csak azokat, amelyek pozitívan hatnak a nyelvoktatásra.

\section{A szaknyelvi vizsgákról általában}

A szaknyelvi vizsgáztatás mibenléte, illetve létjogosultsága az újkori nyelvvizsgáztatás korai szakaszának kedvelt témája volt a Porta Lingua köteteiben. 2002 és 2007 között öt, 2019-ben pedig egy cikk is ezt a témát boncolgatta. A korai érdeklődés logikus, hiszen a 2000 előtti korszak szakmaival bővített nyelvvizsgája helyett immár szaknyelvinek nevezett vizsgák jelentek meg a piacon, amelyek keresték a helyüket az új rendszerben. Rébék-Nagy (2003) éppen ez utóbbi kérdést járja körül, azaz azt, hogy mi a különbség a korábbi és az új vizsga között. A dolgozat arra a következtetésre jut, hogy a szaknyelvi vizsga sokkal megbízhatóbb képet nyújt a vizsgázók szaknyelvhasználati képességeiről, mint a szakmai anyaggal bővített állami nyelvvizsga, mert a feladatokban jóval nagyobb számban fordulnak elö közvetlenül a szaknyelvhasználatot igénylő kontextusok, míg a szakmaival bővített nyelvvizsgákat közvetett mérési módszerek, például nyelvtani tesztek is jellemezték.

G. Havril $(2005,2006)$ két tanulmányban is érvel a szaknyelvi vizsgák létjogosultsága mellett. A 2005-ös cikkben a szaknyelvi vizsgák két nagyon lényeges kérdését, az autentikusság és a szaknyelvhasználati vizsgaszituáció témáját járja körül, valamint vizsgálja a szaknyelvi készség mibenlétét is. 2006-ban pedig azt az egyszerünek látszó kérdést teszi fel, hogy kell-e a szaknyelvet tesztelni. Megítélése szerint igen, mert a szaknyelvi vizsga célja a szaknyelvi kompetencia mérése és értékelése, mely a nyelvtudás mellett magában foglalja a szakmai háttérismeretet is, amelynek mélysége kulcskérdése a szaknyelvi vizsgáztatásnak.

Rébék-Nagy 2005-ös cikke szintén a szakmai háttérismeretek fontosságát hangsúlyozza és ehhez kapcsolódóan a szaknyelvtudás szintjeinek rendszerben történő meghatározásához nyújt segítséget oly módon, hogy Hoffmann (1984) alapján a szaknyelvi kommunikációt az absztrakció foka szerint osztályozza, például megkülönbözteti a tudósok egymás közötti kommunikációját a tudósok asszisztenseikkel folytatott kommunikációjától. A szakmai háttérismeretek fontossága az egészségügyi szaknyelvi vizsgák esetében is górcső alá került (Hegedűs, 2019). A kérdőíves kutatás azt vizsgálta, hogy a háttérismeret vagy a nyelvtudás játszik-e nagyobb szerepet a nyelvvizsga teljesítésében. Következtetései szerint mindkettőnek fontos a szerepe, azonban a nyelvtudás, kismértékben 
ugyan, de fontosabb a kettő közül. A háttérismeret sem konstruktumirreleváns tényezőnek, sem önálló konstruktumnak nem tekinthető, mert a szaknyelvtudás lényege a feltételezett, de önállóan nem mért háttérismeret és a nyelvtudás közötti interakció.

Rébék-Nagy (2002) a vizsgáztatók szempontjából vet fel egy sokakat feszítő kérdést, nevezetesen azt járja körül, hogy egy bölcsészdiplomával rendelkező nyelvtanárt mi jogosít fel arra, hogy más szakmák szakembereinek nyelvi készségeit mérje. Válasza erre a kérdésre az, hogy magát a szakmát csak a müvelt laikus szintjén kell ismerni, viszont a szakmai nyelvhasználat konvencióit és a szakemberek nyelvhasználatának tartalmi és formai oldalát professzionálisan. Ezekből következően van „keresnivalója” egy bölcsész vizsgáztatónak a szaknyelvi vizsgán.

\section{A szintillesztésről}

A szaknyelvi vizsga mibenlétéről szóló tanulmányok 2008-tól már nem jelentek meg a kötetekben, a fent említett 2019-es Hegedủs cikk inkább kivételnek tekinthető. Helyüket a hazai nyelvvizsgáztatási szakmát a 2000-es évek közepétől legalább öt éven keresztül intenzíven foglalkoztató szintillesztés váltotta fel, mint központi téma. Ez nem csoda, hiszen a NYAT felhívása és a vonatkozó kormányrendelet minden magyarországi vizsgaközpont számára kötelezővé tette nyelvvizsgarendszerének a Közös Európai Referenciakeret (KER) skáláihoz való illesztését. 2004 és 2006 között, azaz három év alatt négy szerző tollából öt cikk is ezzel a kérdéssel foglalkozott. Az írások két csoportra oszthatóak: egyrészt elméletibb jellegüekre, másrészt pedig magyar központok konkrét szintminősítési beszámolóira.

Az előbbiekhez tartozik Rébék-Nagy (2004) tanulmánya, amelyben két fontos megállapítást tesz. Az egyik, hogy a szaknyelvi vizsgák szintezésénél a szaknyelvhasználat sajátosságai nem hanyagolhatóak el; a másik pedig, hogy a szükségletelemzés szerves módon határozza meg a vizsgák tartalmát és szintjeit. Dávid (2005) a szintek validálásáról szóló elméleti cikkének tanulságai bármilyen típusú nyelvvizsgára alkalmazhatóak. Kalibrált referenciafeladatok hiányában tesz javaslatot egy lehetséges szintminősítési módszertanra. Mai szemmel nagyon érdekes azt látni, hogy 2005-ben még volt remény arra, hogy majdan lesznek olyan kalibrált referenciafeladatok, amelyek segítségével viszonylag egyértelmüen lehet egy nyelvvizsga szintjeit érvényesíteni. Ilyen feladatok sajnos azóta sem készültek.

Benke (2006) az akkor még BGF (Budapesti Gazdasági Főiskola), ma már BGE (Budapesti Gazdasági Egyetem) nyelvvizsgarendszerének 
szintillesztési munkáiról számol be. Kitér mind a produktív, mind pedig a receptív készségek illesztésének kérdéseire. A munka során felgyülemlett tapasztalatai szerint probléma lehet a kevésbé gyakran oktatott nyelvek esetén a megfelelő létszámú szintminősítő teamek létrehozása, illetve a kétnyelvü és a szaknyelvi vizsgákhoz kapcsolódó szintleírások hiánya. Megállapítja azonban azt is, hogy a tapasztalatok szerint a meglévő skálák is megfelelően alkalmazhatók a szaknyelvi feladatok és teljesítmények szintmeghatározásához. Kitér továbbá a KER familiarizáció alapvető fontosságára, valamint a belső és a külső validitás kölcsönös összefüggéseire. Szőke (2006) szintén a BGF szintminősítési munkálatairól számol be, nevezetesen a német középfokú nyelvvizsga írásfeladatának és a szóbeli vizsga feladatainak értékelése során tapasztalt nehézségekről. A tanulmány egyik legfontosabb következtetése, Benke (2006) megállapításához csatlakozva, hogy a KER skáláit szakmai nyelvvizsga esetén is lehetséges alkalmazni.

Rébék-Nagy (2006) az ETS (Educational Testing System) által Utrechtben rendezett többnapos, sikeres szintminősítési workshop tapasztalatairól számol be, amelynek során részletesen leírja a folyamat módszertani lépéseit. A mühelymunka azt a célt tüzte maga elé, hogy a B1 és C1 szinthez szükséges angol nyelvi minimumszinteket meghatározza a TSE (Test of Spoken English) és a TOEFL (Test of English as a Foreign Language) vizsgákon. A folyamat szakaszai a magyar központok számára is mintául szolgálhattak.

\section{A szükségletelemzésről}

Rébék-Nagy (2004) tanulmánya ugyan tesz róla említést, de érdekes módon a szükségletelemzés, a szaknyelvi vizsgák kidolgozásának egyik alapköve, csupán két cikk fókuszaként jelenik meg a 18 év alatt. Az egyik gyakorlati, a másik elméleti jellegü. A gyakorlati jellegü tanulmány (Tolnai, 2005) a Rendőrtiszti Főiskola rendvédelmi szakmai nyelvvizsgaközpontjának akkreditációjához készített szükségletelemzési kérdőívet elemzi részletesen, amelynek segítségével a vizsgarendszer feladatai meghatározásra kerültek. Ez a vizsgarendszer végül nem indult be, melynek oka jelen sorok írója előtt ismeretlen. Az elméleti jellegü tanulmányban G. Havril (2007) a szükségletelemzés melletti érveket sorolja fel és rámutat arra, hogy az általános vizsgákkal ellentétben a szükségletelemzéssel nagyon pontosan körülhatárolhatóak egy adott szakma nyelvi igényei. 


\section{Müködő vizsgarendszerek fejlesztéséről}

Minden vizsgarendszer és különösen a szaknyelvi vizsgarendszerek elemi érdeke rendszerszerüen ellenőrizni müködésük érvényességét. Tóth (2004) angol nyelvü tanulmányában arra hívja fel a figyelmet, hogy mind a vizsgázóktól, mind pedig a vizsgaeredmények felhasználóitól folyamatosan kell gyüjteni információkat a rendszer beválását illetően, amely információk helyes felhasználása növelheti a rendszer validitását. Egy másik cikkében Tóth (2006) a Zöld Út szaknyelvi nyelvvizsgarendszernél bevezetett változtatásokról számol be, amelyeket az addigi múködésük tapasztalatai és a rendszeres visszajelzések alapján hoztak. Ezek a változások a feladatokra szánt időkeretet, a súlyozást és a fordítás értékelési rendszerének finomítását jelentették.

Dévény és Loch szintén két tanulmányban (2005 és 2006) a BGF vizsgarendszerének validitásával foglalkozott. 2005-ben a szóbeli vizsgafeladatokat értékelték a vizsgázók szemszögéből, azaz azt vizsgálták, hogy ilyen típusú feladatokkal fognak-e majd találkozni a való életben is. A kutatás eredménye szerint a négy BGF feladat közül három autentikus, de a társalgás szakmai témáról feladat életszerüségét a vizsgálat megkérdőjelezte. A szerzőpáros egy évvel későbbi cikke nagyon izgalmas kutatást mutat be (Dévény és Loch, 2006), amelynek során a BGF gazdasági nyelvvizsgájának felszíni validitás-vizsgálatát végezték el. Arra keresték a választ, hogy egyrészt a vizsgázók és a vizsgáztatók mennyiben találják alkalmas és autentikus mérőeszköznek az egyes vizsgafeladatokat, másrészt pedig a vizsgázók milyennek ítélték meg saját nyelvi teljesítményüket. Az eredmények azt mutatták, hogy a vizsgázók 50\%-a érezte úgy, hogy teljesítménye összhangban volt tényleges tudásával, és $20 \%$-uk határozottan úgy vélte, hogy teljesítménye nem tükrözte tudását. A szerzők megállapítása szerint az eredmények pontos magyarázatához további vizsgálódások szükségesek.

\section{Eredményszámítási módszerekről}

2011-től kezdődően sorban jelentek meg azok a cikkek, amelyek a különböző eredményszámítási módszerek elméletéről és gyakorlatáról számoltak be. Lukácsi több cikkében $(2011,2013,2014)$ is azt bizonyítja, hogy csak kellő mennyiségü empirikus adattal alátámasztva hasonlíthatóak össze különbözö időszakokban elért vizsgázói teljesítmények, másrészt pedig megfelelő eredményszámítási módszert kell alkalmazni az összehasonlítás és a végső vizsgapontszámok megbízhatósága érdekében. 2011-es tanulmányában az Euro vizsgán szereplő vizsgaismétlők teljesítményét vizsgálta. Kutatásának 
az a konklúziója, hogy akik egyszer megbuktak a vizsgán és másodszor is jöttek, a második alkalommal már jobb eredményt értek el, azaz növekedett a vizsgázói képességszint egyik időszakról a másikra. Lukácsi (2014) egy másik vizsgálata az EuroPro nyelvvizsga adataira támaszkodott. Következtetése szerint nem tartható az a feltételezés, amely szerint a különböző vizsgaidőszakokban vizsgázók képességszintje állandó, amiből az következik, hogy korábban már felhasznált feladatokat kell visszaforgatni a jövőbeni vizsgákba azért, hogy a különböző vizsgaidőszakokban nyújtott teljesítmények összevethetőek legyenek.

Egy évvel korábbi cikkében (Lukácsi, 2013) hat különböző vizsgaidőszakban vizsgálta a vizsgázók angol nyelvi olvasáskészség teljesítményeit az Euro Pro B2 szintü üzleti szaknyelvi vizsgán három különböző adatfeldolgozási eljárás összehasonlításával. Megállapította, hogy a klasszikus és a különböző modern tesztelméleti alapokon nyugvó eljárások között statisztikailag szignifikáns különbségek mutatkoztak, azaz nem mindegy, hogy a központok milyen eljárások segítségével hirdetik ki a vizsgaeredményeket. Ehhez hasonló problémákat feszeget Kiszely (2016) cikke is, amelyben valós vizsgaadatok segítségével bemutatja, hogy ha az íráskészség teljesítményekre adott pontszámokat klasszikus vagy modern tesztelméleti módszerekkel vizsgáljuk, akkor egymástól teljesen különböző vizsgaeredmények is születhetnek. Egy másik cikkében Kiszely (2017) az eredmények kihirdetésére szintén jelentős hatással bíró statisztikai mutatóval, a magyar nyelvvizsgáztatásban nem gyakran alkalmazott eltérő itemműködéssel (angolul DIF: differential item functioning) foglalkozik. A DIF azt jelenti, hogy két egyforma képességü csoport teljesítménye egy bizonyos item esetén statisztikailag szignifikáns különbséget mutat, azaz az egyik csoportot igazságtalanul diszkriminálja. A tanulmány rámutat azon nehézségekre, amelyek a kimutatott DIF-es itemek okainak keresése közben merülnek fel.

\section{A közvetítő készségről}

Az egyes készségek méréséröl nagyon kevés cikk született a 18 év során, ám volt egy közülük, amely egy időben igen nagy figyelmet kapott. Ez a közvetítő készség, amely azért játszott központi szerepet a kutatásokban, mert akkor még a mainál jóval kevesebb egynyelvü vizsga szerepelt a piacon, a kétnyelvü vizsgákban pedig értelemszerủen szerepeltek közvetítési feladatok. A kiemelt figyelem további oka az is, hogy a közvetítői készség megbízható és érvényes értékelhetősége régi viták tárgya (pl. Alderson, 2001), ezért nyilvánvaló, hogy az ezt a készséget külön mérési egységként kezelö 
szaknyelvi vizsgák fejlesztői igyekeztek minél jobban alátámasztani döntésük helyességet.

Benke (2002) arra a kérdésre próbált válaszolni, hogy a közvetítési feladat vajon olyan képességet mér-e, amely a többi készséghez hasonlóan része a vizsgázó nyelvi kompetenciájának, valamint megvizsgálta azt is, hogy vajon nyújt-e többletinformációt a vizsgázó nyelvtudásáról az adott feladat. Két vizsgaidőszak statisztikai elemzése során azt találta, hogy a közvetítés feladat által mért tulajdonságok is a vizsgázó nyelvtudásának részét képezik, ami indokolja a mérésben való szerepeltetését.

Dévény 2008-as és 2010-es cikkeiben a BGF írásbeli és szóbeli közvetítés vizsgafeladataira való felkészülésröl számol be tanári és diák szempontokból. Longitudinális vizsgálatok alapján az írásbeli közvetítési feladatokkal kapcsolatban azt állapítja meg, hogy nagyon gondos és alapos munka folyik a nyelvórákon, amely az írásbeli közvetítési feladatok elökészítésétől az ellenőrzésig terjed (Dévény, 2008). A szóbeli közvetítés feladatra felkészítő gyakorlatok mennyiségével a vizsgára készülő BGF hallgatók azonban kevésbé voltak elégedettek, és a feladattól való félelmük nem csökkent a felkészítés során. A szerző ebből arra a következtetésre jut, hogy jóval hangsúlyosabb szerepet kell játszania a felkészülés során ennek a vizsgafeladatnak (Dévény, 2010).

A közvetítői készség értékelésével kapcsolatosan két cikk is született (Hegedűs 2013, Hegedűs 2014). A 2013-as cikk azt vizsgálta, hogy a PROFEX angol egészségügyi szaknyelvi vizsga C1 szintű nyelvi közvetítő készség két értékelési módszer szerinti értékelése közül melyik a megbízhatóbb. Az egyik egy holisztikus és analitikus módszereket kombináló, a másik pedig egy tisztán holisztikus értékelési metódus volt. A kismintás vizsgálat eredménye szignifikáns különbséget nem mutatott a két értékelés között. A 2014-es tanulmányban pedig Hegedüs azt vizsgálta egy 126 fös mintán, hogy a fordítás vagy a tömörítés méri-e megbízhatóbban a közvetítő készséget B2 szintü angol orvosi szaknyelvi vizsgákon. A kutatás során a szerző azt találta, hogy a tömörítés valamivel megbízhatóbb képet fest a vizsgázók közvetítő készségéről.

\section{Egyes szaknyelvekről}

Magyarországon számos szaknyelvböl lehet államilag elismert vizsgát tenni. A teljesség igénye nélkül lehet gazdasági, idegenforgalmi, kereskedelmi, üzleti, müszaki, egészségügyi vagy katonai vizsgára is jelentkezni. A fenti összegzés alapján látható, hogy a szaknyelvi méréssel és értékeléssel foglalkozó tanulmányok elsősorban a gazdasági, az üzleti, illetve az egészségügyi szaknyelvek körében születtek. Mivel ezekhez a gyakrabban 
kutatott szaknyelvekhez kapcsolódó tanulmányokkal a fentiekben - egyéb nézőpontokból ugyan - már foglalkoztunk, ezért az alábbiakban a magyarországi nyelvvizsgáztatásban legfiatalabb szaknyelvként megjelent tudományos szaknyelv körében végzett kutatásokat helyezzük fókuszba.

Füköh két tanulmányban elemzi (2018 és 2019) az Euroexam C1 szintü angol tudományos szaknyelvi (English for Academic Purposes) vizsgájának validitását. A 2018-as kötetben a vizsga egyik íráskészség feladatához, a formális tranzakcionális emailhez összegyüjtött validitási bizonyítékokat mutatja be. Egyetemi hallgatókkal készített interjúk segítségével megállapítja, hogy ez a feladat a diszkurzív és az érvelő jellegü írások mellett szintén érvényes kommunikációs forma a felsőoktatási kontextusban. A későbbi cikk (Fűköh, 2019) ugyanezen vizsga mindkét íráskészség feladatának a validitás-vizsgálatáról számol be az előkészítési szakasztól az előtesztelés eredményéig, valamint további kutatási irányokat vázol fel az íráskészség feladatok értékelésével kapcsolatban.

\section{Konklúzió}

Jelen cikk azzal a céllal íródott, hogy bemutassa a 2000 óta müködő államilag elismert szaknyelvi vizsgáztatás témakörének megjelenését a 2002 óta megjelentetett Porta Lingua szaknyelvi tanulmányokat tartalmazó sorozat köteteiben. Az írásban bemutattuk azokat a témaköröket, amelyek a kutatókat az évek során leginkább foglalkoztatták. Tettük ezt azért, hogy felrajzoljuk a szaknyelvi vizsgák kutatásának ívét és szerepét a magyarországi nyelvvizsgáztatás újkori történetében. A megjelent tanulmányok közül nem ismertettük az összeset, csak azokra fókuszáltunk, amelyek több kutatót is foglalkoztattak. A vizsgáltakon kívül születtek írások például a különböző készségek méréséről, egyes feladattípusok jellemzőiröl, vizsgaspecifikációkról és vizsgáztató-továbbképzésről is.

A Porta Lingua 18 éve alatt összesen 42 cikk foglalkozott a témával. Megállapítottuk, hogy a sorozat első öt évében több vizsgáztatással foglalkozó tanulmány jelent meg, mint a következő 13 év alatt összesen. Kezdetben elsősorban a szaknyelv és mérésének mibenléte foglalkoztatta a kutatókat, majd következett a szintillesztési fókusz, amit eredményszámítási kutatások sora zárt. Ezek mellett született néhány tanulmány a szükségletelemzésről, a vizsgák érvényességének folyamatos fenntartásáról és a közvetítő készségről. A különböző szaknyelvek közül a legtöbb a gazdasági, az üzleti és az egészségügyi nyelvvizsgákkal foglalkozott. Jelen cikk írásának pillanatában a legkurrensebb téma a tudományos szaknyelv kutatása. 
Megállapítottuk azt is, hogy a 18 év alatt összességében nagyon kevés cikk összpontosított az államilag elismert szaknyelvi vizsgáztatás témakörére, aminek több oka is lehet. Az egyik az, hogy egész egyszerúen kevés kutatót foglalkoztatott a téma, a másik pedig, hogy az adatok nehezen hozzáférhetőek külső, a vizsgaközpontok kötelékébe nem tartozó kutatók számára. Egy harmadik ok az is lehet, hogy a szaknyelvi vizsgák iránti sokkal kisebb vizsgázói érdeklődés tükröződik a kutatói érdeklődésben is, bár ennek az ellenpróbáját is el kellene végezni, azaz megvizsgálni a nagy vizsgázói tömegeket vonzó általános nyelvvizsgák tudományos feldolgozottságát is. A kép teljességéhez azonban az is hozzátartozik, hogy államilag elismert szaknyelvi vizsgáztatásról nem csupán a Porta Linguá-ban jelentek meg cikkek, hanem egyéb periodikákban is, például a BGE Nyelvvilág című folyóiratában, a MANYE köteteiben, vagy az azóta megszünt Nyelvinfo-ban.

\section{Hivatkozások}

Alderson, C. (2001): The lift is being fixed. You will be unbearable today. A 10. Magyar Macmillan Konferencián elhangzott plenáris előadás

Benke, E. (2002): Amit a számok közvetítenek. In: Porta Lingua-2002. Szaknyelvoktatásunk az EU kapujában. SZOKOE: Debrecen

Benke, E. (2006): Szaknyelvi vizsgák harmonizációja a Közös Európai Referenciakeret szintjeivel - gyakorlati tapasztalatok. In: F. Silye, M. (szerk.) (2006): Porta Lingua - 2006. Utak és perspektívák a hazai szaknyelvoktatásban és -kutatásban. SZOKOE: Debrecen

Dávid, G. (2005): Nyelvvizsgaszintek validálása: lehetőségek és korlátok. In: F. Silye, M. (szerk.) (2005): Porta Lingua - 2005. Szakmai nyelvtudás - szaknyelvi kommunikáció. SZOKOE: Debrecen

Dévény, Á. - Loch, Á. (2005): A szóbeli vizsgafeladatok értékelése a vizsgázók szemszögéből (Vizsgafeladatok vagy valós nyelvi tevékenységek?) In: F. Silye, M. (szerk.) (2005): Porta Lingua - 2005. Szakmai nyelvtudás - szaknyelvi kommunikáció. SZOKOE: Debrecen

Dévény, Á. - Loch, Á. (2006): Teljesítmény-önértékelés a nyelvvizsgaeredmények tükrében. In: F. Silye, M. (szerk.) (2006): Porta Lingua - 2006. Utak és perspektívák a hazai szaknyelvoktatásban és -kutatásban. SZOKOE: Debrecen

Dévény, Á. (2003): Az idegen nyelvi tesztelés etikai problémái. In: F. Silye, M. (szerk.) (2003): Porta Lingua - 2003. Cikkek, tanulmányok a hazai szaknyelvoktatásról és kutatásról. SZOKOE: Debrecen

Dévény, Á. (2008): Az érem két oldala: felkészülés az írásbeli közvetítés vizsgafeladatra tanár és diák szemmel. In: F. Silye, M. (szerk.) (2008): Porta Lingua - 2008. Szakember, szaktudás, szaknyelv. SZOKOE: Debrecen

Dévény, Á. (2010): Felkészülés a szóbeli idegen nyelvi közvetítés vizsgafeladatra. In: F. Silye, M. (szerk.) (2010): Porta Lingua - 2010. Tudományterületek és nyelvhasználat. SZOKOE: Debrecen 
Fischer, M. (2016): Mit üzennek előadásaink, mit rejtenek írásaink? In: Bocz, Zs. Besznyák R. (szerk.) (2016): Porta Lingua - 2016. A szaknyelv rétegzödése a szakmában, az oktatásban és a kutatásban. SZOKOE: Budapest

Füköh, B. (2018): Student interviews in establishing the context validity of an EAP writing task. In: Bocz, Zs. - Besznyák, R. (szerk.) (2018): Porta Lingua-2018.

Tudásmegosztás, értékközvetités, digitalizáció - trendek a szaknyelvoktatásban és kutatásban. SZOKOE: Budapest

Füköh, B. (2019) Kutatáson alapuló tesztfejlesztés - írásfeladatok egy angol tudományos szaknyelvi vizsga számára. In: Bocz, Zs. - Besznyák, R. (szerk.) (2019): Porta Lingua - 2019. Interdiszciplináris megközelitések a szaknyelvoktatásban és kutatásban. SZOKOE: Budapest

G. Havril, Á. (2005): Gondolatok a szaknyelvi vizsgákról. In: F. Silye, M. (szerk.) (2005): Porta Lingua - 2005. Szakmai nyelvtudás - szaknyelvi kommunikáció. SZOKOE: Debrecen

G. Havril, Á. (2006): Miért kell a szaknyelvet tesztelni? In: F. Silye, M. (szerk.) (2006): Porta Lingua - 2006. Utak és perspektívák a hazai szaknyelvoktatásban és kutatásban. SZOKOE: Debrecen

G. Havril, Á. (2007): Szükségletelemzés a szaknyelvi vizsgákon. In: F. Silye, M. (szerk.) (2007): Porta Lingua - 200.7 Szaknyelvoktatásunk - határokon átívelö híd. SZOKOE: Debrecen

Hegedűs, A. (2013): C1 szintű nyelvi közvetítő készség értékelése a PROFEX szaknyelvi vizsgán. In: F. Silye, M. (szerk.) (2013): Porta Lingua - 2013. Innováció és nemzetközi együttmüködés a szaknyelv oktatásában és kutatásában. SZOKOE: Debrecen

Hegedüs, A. (2014): Nyelvi közvetítőkészség mérése angol orvosi szaknyelvi vizsgákon. In: Bocz, Zs. (szerk.) (2014): Porta Lingua - 2014. Szaknyelvi regiszterek és használati színterek. SZOKOE: Budapest

Hegedűs, A. (2019): A háttérismeret szerepe az orvosi szaknyelvvizsgákon. In: Bocz, Zs. Besznyák, R. (szerk.) (2019): Porta Lingua - 2019. Interdiszciplináris megközelitések a szaknyelvoktatásban és -kutatásban. SZOKOE: Budapest

Hoffmann, L. (1984): Kommunikationsmittel Fachsprache. Akademie Verlag: Berlin

Kiszely, Z. (2016): Igazságos(abb) értékelés a magyar nyelvvizsga-szabályozás keretein belül? In: Bocz, Zs. - Besznyák, R. (szerk.) (2016): Porta Lingua - 2016. A szaknyelv rétegzödése a szakmában, az oktatásban és a kutatásban. SZOKOE: Budapest

Kiszely, Z. (2017): Eltérő itemműködés és a klasszikus tesztelemzés. In: Bocz, Zs. Besznyák, R. (szerk.) (2017): Porta Lingua - 2017. Szaknyelvhasználat: a tudomány és a szakma nyelvének alkalmazása. SZOKOE: Budapest

Kiszely, Z. (2018): Mit tanulhat a nyelvoktatás a nyelvvizsgáztatástól? In: Bocz, Zs. Besznyák, R. (szerk.) (2018): Porta Lingua - 2018. Tudásmegosztás, értékközvetités, digitalizáció - trendek a szaknyelvoktatásban és -kutatásban. SZOKOE: Budapest

Lukácsi, Z. (2011): Variation is unsuccesful candidates' performance levels during the administration of consecutive examinations. In: F. Silye, M. (szerk.) (2011): Porta Lingua - 2011. A szaknyelvi kompetenciafejlesztéstöl a munkaerőpiacig. SZOKOE: Debrecen 
Lukácsi, Z. (2014): A tesztlépések ismétlésének jelentősége a szaknyelvi vizsgák egyenértéküsítésében. In: Bocz, Zs. (szerk.) (2014): Porta Lingua-2014. Szaknyelvi regiszterek és használati szinterek. SZOKOE: Budapest

Lukácsi, Z. (2013): Teljesítmény vs. eredmény: Adatfeldolgozási eljárások hatásai nyelvvizsgák értékelésében. In: F. Silye, M. (szerk.) (2013): Porta Lingua - 2013. Innováció és nemzetközi együttmüködés a szaknyelv oktatásában és kutatásában. SZOKOE: Debrecen

Rébék-Nagy, G. (2003): Szakmaival bővített-e a szaknyelvi vizsga? In: F. Silye, M. (szerk.) (2003): Porta Lingua - 2003. Cikkek, tanulmányok a hazai szaknyelvoktatásról és kutatásról. SZOKOE: Debrecen

Rébék-Nagy, G. (2005): A szaknyelvtudás szintjei. In: F. Silye, M. (szerk.) (2005): Porta Lingua - 2005. Szakmai nyelvtudás - szaknyelvi kommunikáció. SZOKOE: Debrecen

Rébék-Nagy, G. (2002): Szaknyelvi-e a szaknyelvi vizsga, avagy lehetünk-e proféták bölcsészdiplomával? In: Porta Lingua - 2002. Szaknyelvoktatásunk az EU kapujában. SZOKOE: Debrecen

Rébék-Nagy, G. (2004): A magyarországi szaknyelvi vizsgák szintjei a Közös Európai Referenciakeret tükrében. In: F. Silye, M. (szerk.) (2004): Porta Lingua - 2004. A szaknyelvtudás esélyteremtö ereje. SZOKOE: Debrecen

Rébék-Nagy, G. (2006): Szintező nyelvvizsgák vizsgaspecifikációjának átalakítása a Közös Európai Referenciakeret tükrében. In: F. Silye, M. (szerk.) (2006): Porta Lingua2006. Utak és perspektívák a hazai szaknyelvoktatásban és -kutatásban. SZOKOE: Debrecen

Sturcz, Z. (2007): Előszó. In: F. Silye, M. (szerk.) (2007): Porta Lingua - 2007. Szaknyelvoktatásunk - határokon átívelö híd. SZOKOE: Debrecen

Szőke, A. (2006): Vélemények a Közös Európai Referenciakeretről. In: F. Silye, M. (szerk.) (2006): Porta Lingua - 2006. Utak és perspektívák a hazai szaknyelvoktatásban és -kutatásban. SZOKOE: Debrecen

Tolnai, L. (2005): Szükségletelemzés a Rendőrtiszti Főiskola rendvédelmi szakmai nyelvvizsgaközpontjának akkreditációjához. In: F. Silye, M. (szerk.) (2005): Porta Lingua - 2005. Szakmai nyelvtudás - szaknyelvi kommunikáció. SZOKOE: Debrecen

Tóth, I. (2004): Student/teacher feedback and ongoing validation. In: F. Silye, M. (szerk.) (2004): Porta Lingua - 2004. A szaknyelvtudás esélyteremtö ereje. SZOKOE: Debrecen

Tóth, I. (2006): Vizsgafejlesztés- és „,karbantartás” a Zöld Út szaknyelvi nyelvvizsgarendszernél. In: F. Silye, M. (szerk.) (2006): Porta Lingua - 2006. Utak és perspektivák a hazai szaknyelvoktatásban és -kutatásban. SZOKOE: Debrecen 